\title{
Neurofibromatosis type 2: growth stimulation of mixed acoustic schwannoma by concurrent adjacent meningioma: possible role of growth factors
}

\section{Case report}

Roberto Pallini, M.D., Angelo Tancredi, M.D., Patrizia Casalbore, Delio Mercanti, Luigi M. Larocca, M.D., Alessandro Consales, M.D., Liverana Lauretti, M.D., and Eduardo Fernandez, M.D.

Institutes of Neurosurgery and Pathology, Catholic University School of Medicine, Rome, Italy; and Institutes of Neurobiology and Cell Biology, Consiglio Nazionale delle Ricerche, Rome, Italy

The authors report the case of a young man suffering from neurofibromatosis type 2 (NF2) who harbored bilateral acoustic schwannomas and a parasellar meningioma. Neuroimaging studies performed during a 4-year follow-up period showed that the bilateral schwannomas had grown very little and at similar rates. However, after the meningioma had infiltrated the tentorium and approached the ipsilateral schwannoma at the incisura, both Schwann cell tumors started to grow rapidly, particularly the one adjacent to the meningioma, of which the percentage of annual growth rate increased by approximately a factor of $10^{2}$. At the same time, magnetic resonance imaging showed that this tumor also changed its features. During surgery, the acoustic schwannoma was firmly adherent to both meningioma and tentorium. Histological examination revealed meningotheliomatous cells in the schwannoma adjacent to the meningioma. Antiphosphotyrosine immunoblotting of PC12 cells was compatible with the presence of an epidermal growth factor (EGF)-like molecule in the cerebrospinal fluid (CSF) of the patient. This factor was not detected in the CSF of five other NF2 patients, two of whom bore associated bilateral acoustic schwannomas and meningioma in remote locations. It is hypothesized that the meningotheliomatous cells infiltrating the schwannoma triggered an autocrine/paracrine growth-stimulatory mechanism that involved an EGF-like factor.

Key Words * meningothelial cells * mixed tumor * neurofibromatosis * acoustic schwannoma * epidermal growth factor * cerebrospinal fluid

Multiple, contemporarily slow-growing, and mixed central tumors are typical features of neurofibromatosis type 2 (NF2). $[8,12,13,17,30,32,44,47,50,51,57]$ The genesis of such tumors is still a subject of speculation. Total or partial loss of chromosome 22, which would contain a suppressor gene that inhibits the genesis of several neoplasms (meningiomas, schwannomas, neurofibromas),[6,21,43,46,49,55] as well as the action of growth factors (GFs) derived from sources 
within or outside the developing tumor,[2,4,7,15,22,27,29,31,33,34,45,52,58,59] have been hypothesized. We report the case of a young man suffering from NF2, who harbored bilateral acoustic schwannomas and a skull base meningioma that had grown adjacent to one of the schwannomas. This case suggests that a GF, which belongs to the epidermal growth factor (EGF) family, may be implicated in the autocrine/paracrine growth stimulation of acoustic schwannomas.

\section{CASE REPORT}

This 17-year-old right-handed boy experienced onset of symptoms in May 1988 with partial motor seizures. Computerized tomography showed a 6 X 6.5 X 6.2-cm homogeneously enhancing mass lesion in the left parasellar area and small bilateral cerebellopontine angle (CPA) tumors. He had undergone surgery twice (August 1988 and March 1989) at another institution for partial resection of the parasellar tumor with a diagnosis of syncytial meningioma. In the following 4 years, magnetic resonance (MR) imaging studies documented regrowth of the meningioma that extended to the cavernous sinus area, sella turcica, and tentorium (Fig. 1 left and center). At the same time, the CPA tumors had grown very little (Fig. 1 center and right; Table 1).
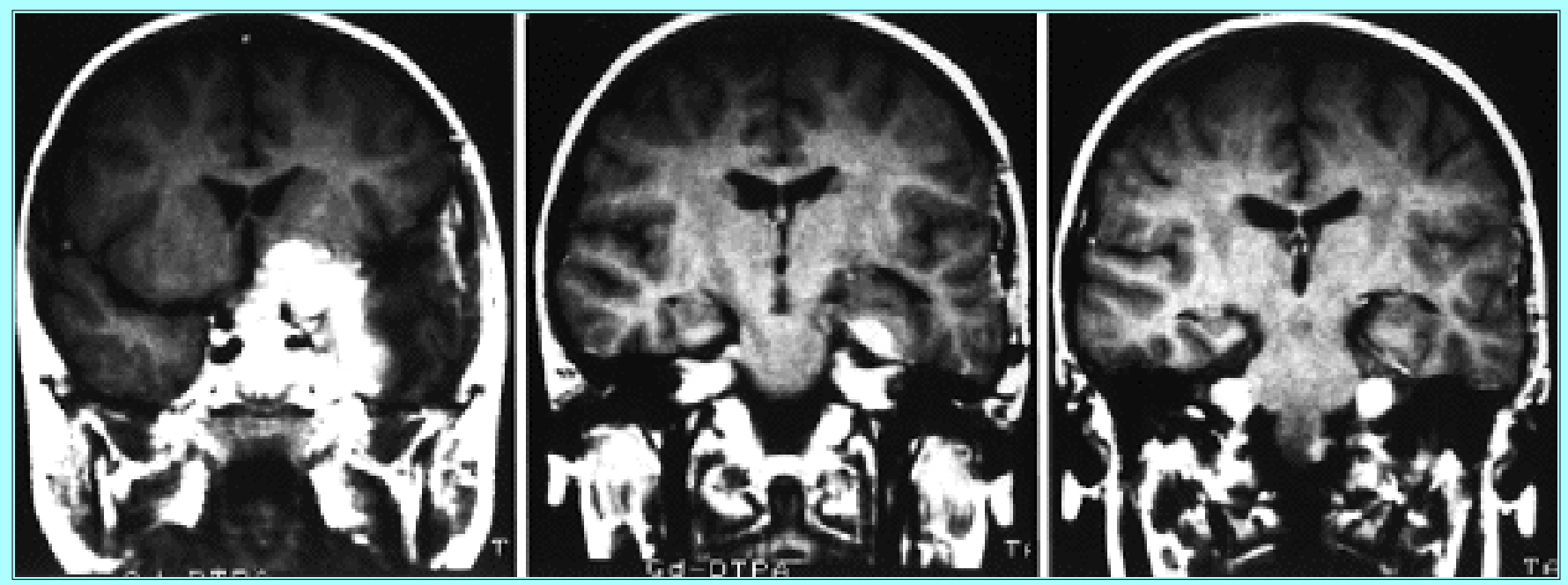

Fig. 1. Enhanced $T_{1}$-weighted coronal MR images (March 1992) showing the left parasellar meningioma with cavernous sinus involvement (left) and the bilateral symmetrically growing acoustic schwannomas (center and right). Note that the meningioma has extended over the tentorium approaching the ipsilateral schwannoma (center). 


\section{TABLE 1}

SUMMARY OF DIMENSONAL DATA OF THE BILATERAL ACOUSTIC SCHWANNOMAS CALCULATED FROM NEUROIMAGING FOLLOW-UP STUDIES IN CASE 1 *

\begin{tabular}{|c|c|c|c|c|c|}
\hline \multirow{2}{*}{$\begin{array}{l}\text { Neur oimaging } \\
\text { Date }\end{array}$} & \multirow{2}{*}{$\begin{array}{c}\text { Follow-up } \\
\text { Interval } \\
\text { (mos) }\end{array}$} & \multicolumn{2}{|c|}{$\begin{array}{l}\text { Yolume of } A c \text { coustic } \\
\text { Sctwannoma }\left(\mathrm{cm}^{3}\right)\end{array}$} & \multicolumn{2}{|c|}{$\begin{array}{c}\text { Amnual } \\
\text { Growth Rate (\&) }\end{array}$} \\
\hline & & Left & Right & Left & Pight \\
\hline July 1988 & none & 1.08 & 1.04 & none & none \\
\hline May 1989 & 10 & 1.12 & 1.13 & 4.4 & 10.3 \\
\hline March 1992 & 44 & 1.73 & 1.61 & 14.8 & 11.6 \\
\hline Septem ber 1993 & 18 & 43.42 & 8.93 & 1673.2 & 369.7 \\
\hline
\end{tabular}

"Tumor wolume was calculated by measuring the enhancing tumor area with planime try. After the tumor areas mas calculated on each image in square millimeters, wolumes were determined in cutic centimeters by multiplication with the distance between adjacent images $(2-5 \mathrm{~mm})$. The initial wolume was estimated from computerized tomography scans; followup wolumes were obtained from MR images.

Suffering from intracranial hypertension, right-sided weakness, speech disturbances, and dysphagia, the patient was admitted to our institution in September 1993. Physical examination revealed stigmata of NF2 (subcutaneous nodules, "café-au-lait" spots), right-sided hemiparesis, motor aphasia, left-sided cerebellar syndrome and deafness, right hypoacusis, and palsy of the ninth, 10th, and 11th cranial nerves on the left. Magnetic resonance imaging showed that the meningioma had grown adjacent to the ipsilateral CPA tumor at the tentorial incisura (Fig. 2 left and center); moreover, the CPA tumors of both sides had increased considerably in size, particularly the one on the left side (Fig. 2 center and right; Table 1). This schwannoma had also changed its features on MR imaging, enhancing less homogeneously after gadolinium administration and appearing less hyperintense on $\mathrm{T}_{2}$-weighted sequences as compared with both previous MR studies and the contralateral schwannoma.
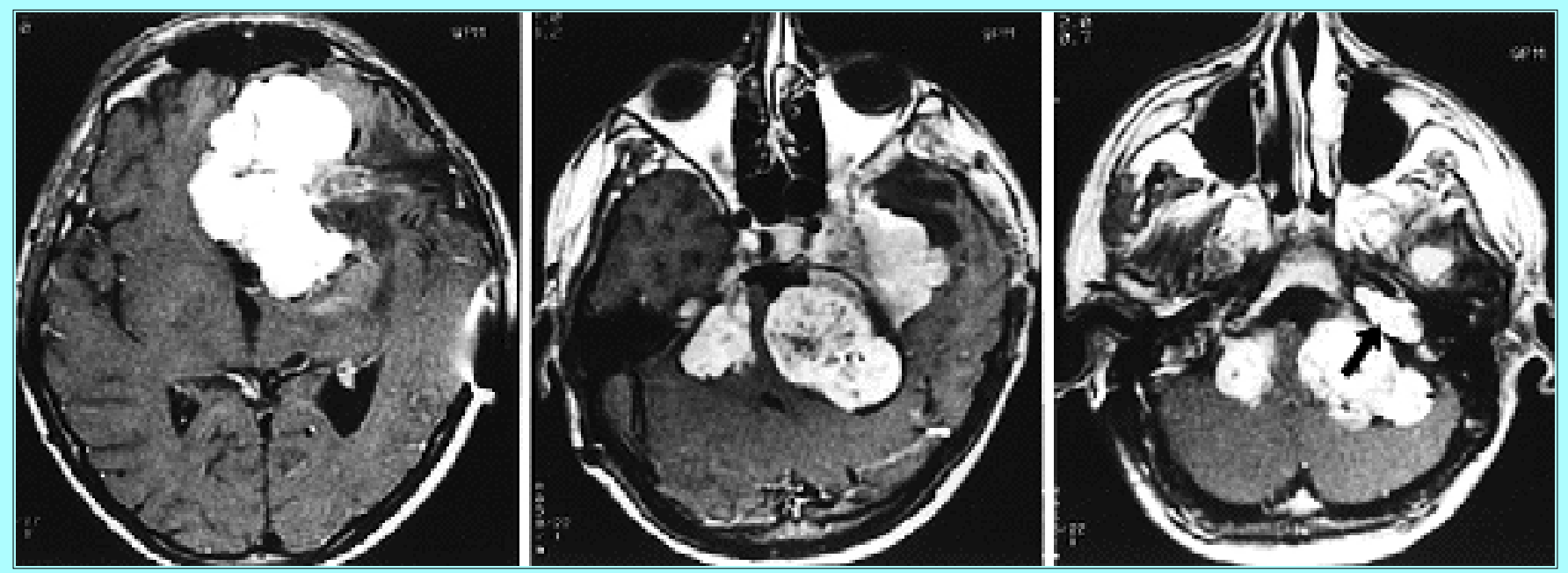

Fig. 2. Enhanced $T_{1}$-weighted axial MR images (September 1993) showing the meningioma in the frontobasal area (left) and medial temporal fossa (center), and the bilateral acoustic schwannomas (center and right). Note the close relationship between the meningioma and the ipsilateral schwannoma at the tentorial incisura (center). The left schwannoma has infiltrated the temporal bone (right) (arrow).

Staged surgical treatment was planned. At the first operation (March 1994), a partial resection of the meningioma was performed and a ventriculoperitoneal shunt was placed. Histological examination 
confirmed the previous diagnosis. In the second (October 1994) and third stages (June 1995), the left and right CPA tumors were partly removed via retrosigmoid craniectomies. During surgery, the cranial portion of the left CPA tumor was firmly attached both to the capsule of the meningioma at the tentorial hiatus and to the tentorium.

Pathological Examination. Approximately $85 \%$ of the left CPA tumor specimen corresponded to a typical schwannoma, with areas of compact fascicular tissue that alternated with areas of loose-textured spongy tissue. In the remaining areas, lobules of cells with round to oval nuclei and indistinct cell borders resembling islands of meningotheliomatous cells were found (Fig. 3 left). At the periphery of the lobules, meningotheliomatous cells were grouped in strings clearly separated from schwannomatous tissue by a thin fibrous wall. When sections were analyzed after S-100 protein immunolabeling, Schwann cells appeared strongly and uniformly stained, whereas lobules and strings of meningotheliomatous cells were unstained (Fig. 3 right). The latter showed a weak membranous pattern of immunoreaction for epithelial membrane antigen that was absent in Schwann cells. These histological and immunohistochemical findings allowed for a diagnosis of schwannoma with meningotheliomatous foci. Proliferative activity, as evidenced by mitotic figure counts and proliferating cellular nuclear antigen, ranged from zero to three mitoses or proliferating cellular nuclear antigen-positive cells per $10 \mathrm{hpf}$. The right CPA tumor surgical specimens corresponded to a typical schwannoma.

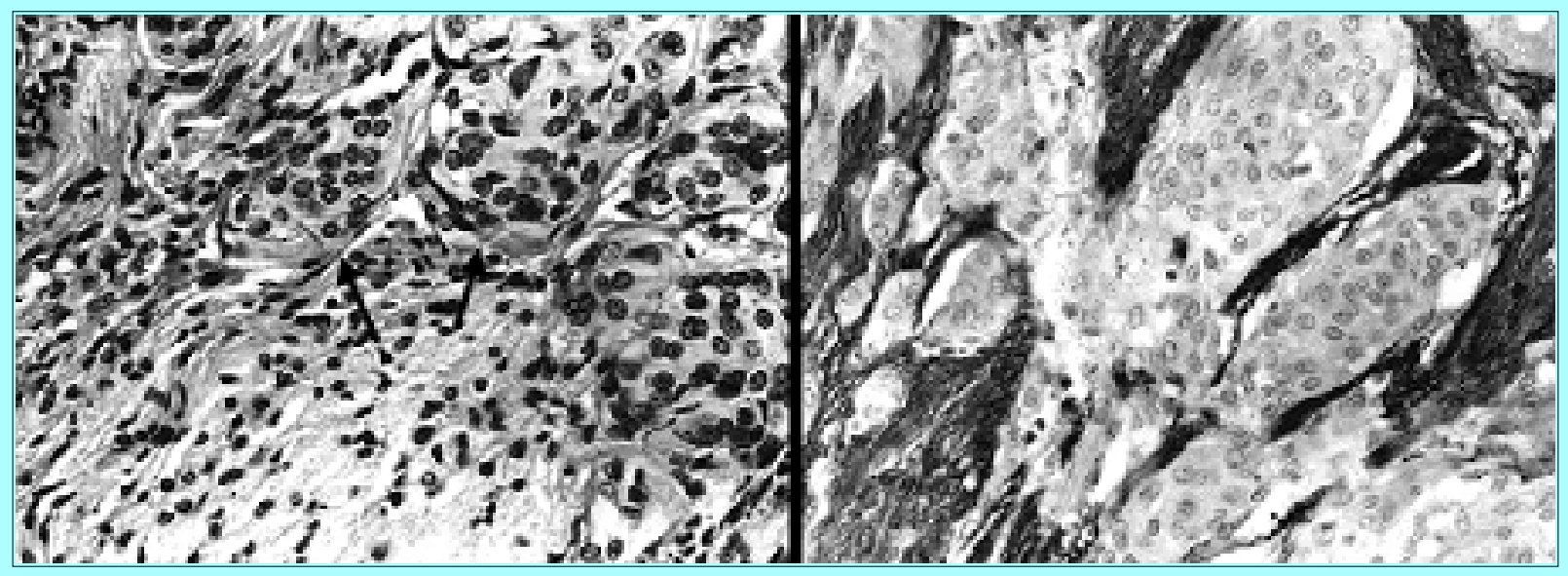

Fig. 3. Photomicrographs showing lobules of meningotheliomatous cells with syncytial appearance growing inside the schwannoma. A thin capsule (arrows) is present between meningothelial lobules and Schwann cells (left) (H \& E). When sections of schwannoma tissue are treated with anti-S-100 protein antiserum, immunostaining is restricted to Schwann cells that surround islands of unstained meningothelial cells (right). Original magnification X 400 .

Cultured rat pheochromocytoma-derived cell line PC12 was used as a model to investigate for the presence of GFs in the cerebrospinal fluid (CSF). Whereas nerve GF (NGF) induces a dramatic differentiation of $\mathrm{PC} 12$ cells to neuronal phenotype, EGF promotes a mitogenic nondifferentiative response that results in an immediate tyrosine phosphorylation of its receptors.[3,39,42]

Bioassay of CSF. Ventricular CSF was obtained from our patient (Case 1) at the time of shunt placement and then, for retesting the results, 1 month later through the reservoir of the ventriculoperitoneal shunt device. For comparison, samples of CSF were also obtained from five other patients (Cases 2-6) suffering from NF2 (Table 2). The patients in Cases 2 and 3 had bilateral acoustic schwannomas with associated meningioma of the parietal convexity and cervical spine, respectively. The patients in Cases 4, 
5, and 6 had bilateral eighth nerve tumors. The patients and/or their parents gave informed consent for $\mathrm{CSF}$ withdrawal and analysis. The CSF samples were immediately frozen at $-70^{\circ} \mathrm{C}$ for storage until use. For analysis, the CSF was concentrated fivefold by ultafiltration with Centricon 3 devices (Amicon, Beverly, MA) and sterile filtered. The PC12 cells were plated on collagenated plastic petri dishes and allowed to grow to confluence in RPMI 1640 supplemented with $10 \%$ heat-inactivated horse serum and $5 \%$ newborn calf serum at $37^{\circ} \mathrm{C}$ in a $5 \% \mathrm{CO}_{2}$ atmosphere in a humidified incubator. The NGF $(50 \mathrm{ng} / \mathrm{ml})$ or volumes of 10,40 , and $50 \mu \mathrm{l}$ of concentrated CSF was added directly to the incubation media. The cultures were observed with the aid of an inverted microscope at specific time intervals. The NGF treatment induced typical morphological cell changes, consisting of the production of short spikes (within 3 hours) and axons (after 8 hours) that were detectable for up to 5 days. Conversely, the addition of CSF from the patients did not induce any persistent phenotypic changes in PC12 cells. These results indicate that the CSF samples did not contain NGF or NGF-like activities.

\begin{tabular}{|c|c|c|c|c|}
\hline & SUMMAR & $\begin{array}{l}\text { TA } \\
\text { F DATA FROM PATIENTS WI } \\
\text { NEUROTRO }\end{array}$ & $\begin{array}{l}\text { E } 2 \\
\text { NF2 INCLUDED FOR CSF AN } \\
\text { C ACTN } T \text { WY }\end{array}$ & S OF \\
\hline & & $\begin{array}{r}\text { Certral T um ors } \\
\text { Bilat Acoustio }\end{array}$ & $\begin{array}{l}\text { ociated with the } \\
\text { thwannoma }\end{array}$ & \\
\hline No. & $\operatorname{sex}$ & Type & Location & CSF Sample \\
\hline $\begin{array}{l}1 \\
2 \\
3 \\
4 \\
5 \\
6\end{array}$ & $\begin{array}{l}17, \mathrm{M} \\
16, \mathrm{~F} \\
23, \mathrm{~F} \\
31, \mathrm{~F} \\
19, \mathrm{M} \\
20, \mathrm{M}\end{array}$ & $\begin{array}{l}\text { syncytial meningioma } \\
\text { syncytial meningioma } \\
\text { fitroblastic meningioma } \\
\text { Grade II astrocytoma } \\
\text { none } \\
\text { none }\end{array}$ & $\begin{array}{l}\text { parasellar, tentorial hiatus } \\
\text { parietal parasagittal } \\
\text { cervical spine } \\
\text { cerebellar hemisphere }\end{array}$ & $\begin{array}{l}\text { lat ventride } \\
\text { lat uentride } \\
\text { lum bar spine } \\
\text { lat uentride } \\
\text { lum bar spine } \\
\text { lum bar spine }\end{array}$ \\
\hline
\end{tabular}

Antiphosphotyrosine Immunoblotting. The PC12 cells were prepared and cultured as above. The growth medium was then replaced with fresh medium without serum and incubated for an additional 12 hours. The cells were then treated with NGF $(100 \mathrm{ng} / \mathrm{ml})$, EGF $(50 \mathrm{ng} / \mathrm{ml})$, or with the same aliquots of CSF as stated in the bioassay for 5 minutes and lysed in sodium dodecylsulfate (SDS) sample buffer containing $1 \mathrm{mM} \mathrm{Na}_{3} \mathrm{VO}_{4}$. Immunoblotting was performed as described by Towbin, et al.[54] The lysates were separated by $7.5 \%$ SDS polyacrylamide gel electrophoresis and subsequently electrotransferred to a polyvinylidene difluoride membrane (Immobilon P; Millipore Corporation, Bedford, MA). After incubation with $5 \%$ bovine serum albumin in tris-buffered saline to block nonspecific binding sites, the filters were incubated overnight at $4^{\circ} \mathrm{C}$ with antiphosphotyrosine antibodies (PY 20; Transduction Laboratories, Lexington, KY). After washing in tris-buffered saline, the secondary antibody (peroxidase-conjugated anti-mouse immunoglobulin $\mathrm{G}$ ) was added for 30 minutes at room temperature. The membranes were washed, soaked in emission chemiluminescence reagent (Amersham, Arlington Heights, IL), and visualized using Hyperfilm ECL. Figure 4 shows the pattern of tyrosine-phosphorylated proteins observed in PC12 cells after stimulation with NGF (lane 2), EGF (lane 3 ), and the CSF from the patient in Case 1 (lanes 4, 5, and 6). The phosphorylated proteins observed at approximately 170-kD in EGF- and CSF-treated cells are thought to be EGF receptors.[42] Analysis of these findings indicates that the CSF in Case 1 contained either EGF or EGF-like molecules. However, the stimulation of PC12 cells with the CSF obtained from the other patients produced no increase in tyrosine phosphorylation of proteins migrating at molecular weights of approximately $170 \mathrm{kD}$. Experiments with the CSF of all the patients, including the two samples from Case 1, were completely repeated, and similar profiles were obtained. 


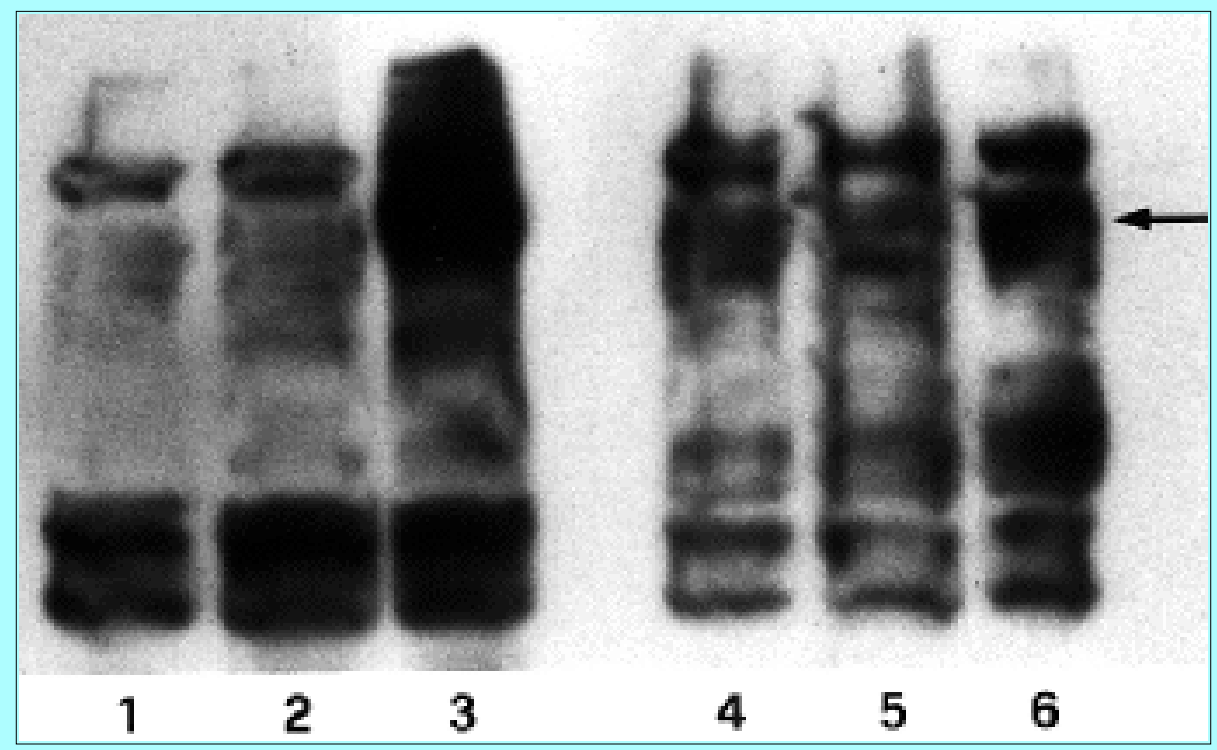

Fig. 4. Tyrosine phosphorylation in PC12 cells treated with NGF (100 ng/ml) (lane 2), EGF $(50 \mathrm{ng} / \mathrm{ml})$ (lane 3), and CSF of the patient in Case 1 (10, 40, and $50 \mu \mathrm{l})$ (lanes 4, 5, and 6) for $5^{\prime}$ at $37^{\circ} \mathrm{C}$. The cells were lysed and cell lysates were fractionated by SDS-polyacrylamide gel elctrophosphoresis, transferred to nitrocellulose, and probed with anti-Ptyr antibody. The band of immunoreactivity observed at approximately $170-\mathrm{kD}$ (arrow) in EGF- (lane 3) and CSF-treated (lanes 4, 5, and 6) cells corresponds to EGF receptors. Lane 1 represents the culture media.

\section{DISCUSSION}

\section{Mixed Acoustic Schwannoma and Meningioma}

The association of meningioma tissue with and within acoustic schwannomas has been known since the writings of Harvey Cushing.[10] Cushing first drew attention to the fact that, in some instances, the microscopic structure of an acoustic schwannoma displays a conspicuously whorled pattern strongly resembling that of certain meningiomas. On the other hand, a meningioma may, in some areas, exhibit certain features that bear such a close resemblance to a schwannoma that the two tumors become almost indistinguishable. Furthermore, in NF2 there is an obvious similarity between the nerve sheath tumor tissue and the fibroblastic variant of meningioma.[14] In spite of the overlapping morphological features, cases have been reported, such as the present one, in which the two components of the mixed acoustic tumor show different antigenic profiles, with S-100 protein immunoreactivity being positive in schwannomatous areas and negative in meningotheliomatous foci.[16]

Linthicum and Brackmann[30] have noted that those acoustic tumors composed of intermixed schwannoma and meningioma can infiltrate the temporal bone. Other authors, however, have not confirmed the aggressive nature of these tumors. [14] The consociation of schwannoma and meningioma has also been described in the neural compartment of the jugular foramen,[35-37] frontal and temporal lobes,[50,51] cerebellar convexity,[50] and spinal cord.[14] There are several possible mechanisms by which to explain the presence of meningioma tissue in a Schwann cell tumor, including divergent differentiation from a common cell line,[20] metaplasia in a typical schwannoma,[5,56] entrapment of hyperplastic arachnoidal cells,[16], and collision of separate tumors in which two contiguous neoplasms merge into one.[48] 


\section{Possible Role of EGF-Like Molecules in Modulating the Growth Rate of Schwannomas}

In NF2, bilateral eighth nerve tumors are known for their potential to reach a remarkable size as well as their propensity for asymmetrical growth.[23,28,32,40] The temporal growth profile of these tumors is unpredictable, with periods of relative stability and phases of growth stimulation during which growth rates ranging from 1.5 to $30 \mathrm{~mm}$ per year have been reported.[9,28,38,41] In our case, however, there is a close temporal relationship between the contact established by the schwannoma and meningioma at the tentorial incisura, increased growth rate of both schwannomas, and MR imaging changes of the schwannoma adjacent to the meningioma. One may speculate that these phenomena may not be coincidental occurrences and that a local factor may be involved. The possibility that the meningioma infiltrated the ipsilateral schwannoma, although not directly demonstrated on serial histological sections, is supported by the surgical findings. It remains difficult, however, to explain the impressive growth of the schwannoma simply by considering the infiltration of meningioma cells, which represented only approximately $15 \%$ of the tumor mass. A feasible explanation may be that the meningioma cells infiltrating the schwannoma triggered an autocrine/paracrine mechanism and that totipotent cells inside the schwannoma responded to the stimulation of tumor-derived GFs. These factors may diffuse into the $\mathrm{CSF}$, thus modulating the growth rate of the contralateral schwannoma.

One major result from this study is that the CSF of our patient contained a GF that induced the molecular differentiation of rat PC12 cells in a manner similar to EGF. This EGF-like factor seems to be related to the mixed tumor itself, not to the NF2 condition per se or to the mere consociation of schwannoma and meningioma, because it was not detected in the CSF of the other NF2 patients, two of whom had associated schwannoma and meningioma. It is known that 85 to $95 \%$ of intracranial meningioma express high levels of the EGF receptor[11,18] and that the growth of meningioma cell cultures is stimulated by EGF.[1] However, an actual secretion of EGF by meningioma cells themselves in an autocrine manner, although demonstrated for several GFs like fibroblast GF, platelet-derived growth factor (PDGF), and insulin-like GF, [29,53] has not been proven. Recently, a schwannoma-derived growth factor (SDGF) has been isolated from a schwannoma cell line as a mitogen and neurotrophic protein that belongs to the EGF family.[25,26] This factor reproduces some of the responses shown in our patient to be elicited by the CSF from PC12 cells, like phosphorylation of cellular proteins. However, SDGF differs from the GF of our patient in that the former, like NGF, induces morphological responses of PC12, whereas the latter, like EGF, does not. It is interesting to note that SDGF activates the EGF receptor and induces receptor kinase activity that is required for SDGF to stimulate DNA synthesis.[24] Thus, it seems reasonable to postulate a condition in which meningioma cells, putatively expressing EGF receptors, infiltrated the Schwann cell tumor and triggered an autocrine mechanism to produce an EGF-like factor.

A similar mechanism has been proposed to have a role in the development and progression of malignant glioma, in which an autocrine and paracrine growth stimulation loop is established between glioblastoma cells that express high levels of PDGF and the PDGF receptors that are present in the hyperplastic capillarities of the tumor.[19]

\section{CONCLUSIONS}

Although the hypothesis noted in this paper is admittedly highly speculative and additional data on patients of this type are needed, the case being described in this report is of particular interest because it provides evidence that an EGF-like activity was associated with the CSF. It will be important in future research to investigate the appearance of specific GFs in the CSF of NF2 patients harboring mixed 
schwannoma and meningioma. This report may also stimulate researchers to study GF expression in cocultures of schwannoma and meningioma cells.

\section{References}

1. Adams EF, Schrell UMH, Fahlbusch R, et al: Hormonal dependency of cerebral meningiomas. Part 2: In vitro effect of steroids, bromocriptine, and epidermal growth factor on growth of meningiomas. $\mathbf{J}$ Neurosurg 73:750-755, 1990

2. Akutsu I, Aida T, Nakazawa S, et al: Localization of acidic and basic fibroblastic growth factor mRNA in human brain tumors. JPN J Cancer Res 82:1022-1027, 1991

3. Alemà S, Casalbore $\mathrm{P}$, Agostini E, et al: Differentiation of PC12 phaeochromocytoma cells induced by $\mathrm{v}$-src oncogene. Nature 316:557-559, 1985

4. Asai K, Hotta T, Nakanishi K, et al: Von Recklinghausen neurofibroma produces neuronal and glial growth-modulating factors. Brain Res 556:344-348, 1991

5. Bigorgne C, Thomine E, Hemet J, et al: [Benign glandular schwannoma and Recklinghausen disease. Report of a case.] Ann Pathol 12:114-120, 1992 (Fr)

6. Bijlsma EK, Brouwer-Mladin R, Bosch DA, et al: Molecular characterization of chromosome 22 deletions in schwannomas. Gen Chromosom Cancer 5:201-205, 1992

7. Brockes JB, Breakefield XO, Martuza RL: Glial growth factor-like activity in Schwann cell tumors. Ann Neurol 20:317-322, 1986

8. Brooks JS, Freeman M, Enterline HT: Malignant "Triton" tumors. Natural history and immunohistochemistry of nine new cases with literature review. Cancer 55:2543-2549, 1985

9. Charabi S, Thomsen J, Mantoni M, et al: Acoustic neuroma (vestibular schwannoma): growth and surgical and nonsurgical consequences of the wait-and-see policy. Otolaryngol Head Neck Surg 113:5-14, 1995

10. Cushing H, Eisenhardt L: Meningiomas. Their Classification, Regional Behaviour, Life History and Surgical End Results. Springfield, Ill: Charles C Thomas, 1938, pp 100-114

11. DiCarlo A, Mariano A, Macchia PE, et al: Epidermal growth factor receptor in human brain tumors. J Endocrinol Invest 15:31-37, 1992

12. Eldridge R: Central neurofibromatosis with bilateral acoustic neuroma. Adv Neurol 29:57-65, 1981

13. Evans DG, Huson SM, Donnai D, et al: A genetic study of type 2 neurofibromatosis in the United Kingdom. I. Prevalence, mutation rate, fitness, and confirmation of maternal transmission effect on severity. J Med Genet 29:841-846, 1992

13. Feigin I: Mixed mesenchymal tumors: meningioma and nerve sheath tumors. J Neuropathol Exp Neurol 37:459-470, 1978

15. Fleming TP, Matsui T, Heidaran MA, et al: Demonstration of an activated platelet-derived growth factor autocrine pathway and its role in human tumor cell proliferation in vitro. Oncogene 7:1355-1359, 
16. Geddes JF, Sutcliffe JC, King TT: Mixed cranial nerve tumors in neurofibromatosis type 2. Clin Neuropathol 14:310-313, 1995

17. Glover TW, Stein CK, Leguis E, et al: Molecular and cytogenetic analysis of tumors in von Recklinghausen neurofibromatosis. Gen Chromosom Cancer 3:62-70, 1991

18. Hawkins RA, Killen E, Whittle IR, et al: Epidermal growth factor receptors in intracranial and breast tumours: their clinical significance. Br J Cancer 63:553-560, 1991

19. Hermanson M, Funa K, Hartman M, et al: Platelet-derived growth factor and its receptors in human glioma tissue: expression of messenger RNA and protein suggests the presence of autocrine and paracrine loops. Cancer Res 52:3213-3219, 1992

20. Hörstadius S: The Neural Crest. Its Properties and Derivatives in the Light of Experimental Research. Oxford: Oxford University Press, 1950

21. Jacoby LB, MacCollin M, Louis DN, et al: Exon scanning for mutation of the NF2 gene in schwannomas. Hum Mol Genet 3:413-419, 1994

22. Kadono T, Soma Y, Takehara K, et al: The growth regulation of neurofibroma cells in neurofibromatosis type-1: increased responses to PDGF-BB and TGF-beta 1. Biochem Biophys Res Commun 198:827-834, 1994

23. Kanter WR, Eldridge R, Fabricant R, et al: Central neurofibromatosis with bilateral acoustic neurinoma: genetic, clinical and biochemical distinctions from peripheral neurofibromatosis. Neurology 30:851-859, 1980

24. Kimura H: Schwannoma-derived growth factor must be transported into the nucleus to exert its mitogenic activity. Proc Natl Acad Sci USA 90:2165-2169, 1993

25. Kimura H, Fischer WH, Schubert D: Structure, expression and function of a schwannoma-derived growth factor. Nature 348:257-260, 1990

26. Kimura H, Schubert D: Schwannoma-derived growth factor promotes the neuronal differentiation and survival of PC12 cells. J Cell Biol 116:777-783, 1992

27. Kousseff BG: The phakomatoses as paracrine growth disorders (paracrinopathies). Clin Genet 37:97-105, 1990

28. Laasonen EG, Troupp H: Volume growth rate of acoustic neuromas. Neuroradiology 28:203-207, 1986

29. Lichtor T, Kurpakus MA, Gurney ME: Expression of insulin-like growth factors and their receptors in human meningiomas. J Neurooncol 17:183-190, 1993

30. Linthicum FH Jr, Brackmann DE: Bilateral acoustic tumors. A diagnostic and surgical challenge. Arch Otolaryngol 106:729-733, 1980

31. Mapstone T, McMichael M, Goldthwait D: Expression of platelet-derived growth factors, transforming growth factors, and the ros gene in variety of primary human brain tumors. Neurosurgery 
32. Martuza RL, Eldridge R: Neurofibromatosis 2 (bilateral acoustic neurofibromatosis). N Engl J Med 318:684-688, 1988

33. Murphy PR, Myal Y, Sato Y, et al: Elevated expression of basic fibroblastic growth factor messenger ribonucleic acid in acoustic neuromas. Mol Endocrinol 3:225-231, 1989

34. Nagashima C, Nakashio K, Fujino T: Meningioma and astrocytoma adjacent in the brain. J Neurosurg 20:995-999, 1963

35. Nager GT: Acoustic neurinomas. Acta Otolaryngol 99:245-261, 1985

36. Nager GT: Acoustic neurinomas. Pathology and differential diagnosis. Acta Otolaryngol 89:252-279, 1969

37. Nager GT: Pathology of the Ear and Temporal Bone. Baltimore: Williams \& Wilkins, 1993

38. Naguib MB, Saleh E, Aristegui M, et al: Decision making in acoustic neuroma management: the only hearing ear. Skull Base Surg 4:32-36, 1994

39. Ohmichi M, Decker SJ, Saltiel AR: Activation of phosphatidylinositol-3 kinase by nerve growth factor involves indirect coupling of the trk proto-oncogene with src homology 2 domains. Neuron 9:769-777, 1992

40. Ojemann RG, Martuza RL: Acoustic neuroma, in Youmans JR (ed): Neurological Surgery, ed 3. Philadelphia: WB Saunders, 1990, Vol 4, pp 3315-3350

41. Pensak ML, Tew JM, Keith RW, et al: Management of the acoustic neuroma in an only hearing ear. Skull Base Surg 1:93-96, 1991

42. Rabin SJ, Cleghon V, Kaplan DR: SNT, a differentiation-specific target of neurotrophic factor-induced tyrosine kinase activity in neurons and PC12 cells. Mol Cell Biol 13:2203-2213, 1993

43. Rey JA, Pestana A, Bello MJ: Cytogenetics and molecular genetics of nervous system tumors. Oncol Res 4:321-331, 1992

44. Riccardi VM: Von Recklinghausen neurofibromatosis. N Engl J Med 305:1617-1627, 1981

45. Ross AH, Herlyn M, Maul GG, et al: The nerve growth factor receptor in normal and transformed neural crest cells. Ann NY Acad Sci 486:115-123, 1986

46. Rouleau GA, Seizinger BR, Wertelecki W, et al: Flanking markers bracket the neurofibromatosis type-2 (NF2) gene on chromosome 22. Am J Hum Genet 46:323-328, 1990

47. Rubenstein AE, Mytilineoau C, Yahr MD, et al: Neurological aspects of neurofibromatosis. Adv Neurol 29:11-21, 1981

48. Russell DS, Rubinstein LJR: Pathology of Tumours of the Nervous System. London: Arnold, 1989, p 501

49. Seizinger BR, Rouleau G, Ozelius LJ, et al: Common pathogenetic mechanisms for three tumor types 
in bilateral acoustic neurofibromatosis. Science 236:317-319, 1987

50. Shuangshoti S, Netsky MG: Neoplasms of mixed mesenchymal and neuroepithelial origin. Relation to "monstrocellular sarcoma" or "giant-celled glioblastoma." J Neuropathol Exp Neurol 30:290-309, 1971

51. Shuangshoti S, Netsky MG, Jane JA: Neoplasms of mixed mesenchymal and neuroepithelial type. With consideration of the relationship between meningioma and neurilemmoma. J Neurol Sci 14:277-291, 1971

52. Sporn MB, Todaro GJ: Autocrine secretion and malignant transformation of cells. N Engl J Med 303:878-880, 1980

53. Todo T, Adams EF, Fahlbusch R, et al: Autocrine growth stimulation of human meningioma by platelet-derived growth factor. J Neurosurg 84:852-859, 1996

54. Towbin H, Staehelin T, Fordon J: Electrophoretic transfer of proteins from polyacrylamide gels to nitrocellulose sheets: procedure and some applications. Proc Natl Acad Sci USA 76:4350-4354, 1979 55. Twist EC, Ruttledge MH, Rousseau M, et al: The neurofibromatosis type 2 gene is inactivated in schwannomas. Hum Mol Genet 3:147-151, 1994

56. Woodruff JM: Peripheral nerve tumors showing glandular differentiation (glandular schwannomas). Cancer 37:2399-2413, 1976

57. Worster-Drought C, Dickson WEC, McMenemey WH: Multiple meningeal and perineural tumors with analogous changes in the glia and ependyma (neurofibromatosis), with report of 2 cases. Brain 60:85-117, 1937

58. Yasuda T, Sobue G, Ito T, et al: Human peripheral nerve sheath neoplasm: expression of Schwann cell-related markers and their relation to malignant transformation. Muscle Nerve 14:812-819, 1991

59. Yasuda T, Sobue G, Mitsuma T, et al: Nerve growth factor receptor immunoreactivity in human benign peripheral nerve sheath tumor. Acta Neuropathol 77:591-598, 1989

Manuscript received January 9, 1998.

Accepted in final form January 19, 1998.

Address reprint requests to: Roberto Pallini, M.D., Department of Neurosurgery, Catholic University School of Medicine, Largo A. Gemelli 8, 00168 Rome, Italy. 